\title{
PENGARUH MOTIVASI TERHADAP PRODUKTIVITAS KARYAWAN BALAI BESAR CISADANE
}

\author{
Sri Yanthy Yosepha \\ Dosen tetap Prodi Manajemen Unsurya \\ yosepha@universitassuryadarma.ac.id
}

\begin{abstract}
ABSTRAK
Tujuan penelitian ini untuk menganalisa mencari pengaruh Motivasi terhadap Produktivitas Karyawan Balai Besar Cisadane. Metode penelitian kuantitatif untuk pengujian yang digunakan dalam penelitian serta menggunakan uji Instrumen penelitian (Uji Validitas \& Uji Reliabilitas), Uji Normalitas dan Uji t. Sehingga nilai konstanta sebesar 9,047 menunjukkan jika Motivasi nilainya adalah 0, maka Produktivitas nilainya positif yaitu sebesar 0,912, nilai koefisien regresi sebesar 0,912 menunjukkan besarnya pengaruh Motivasi terhadap Produktivitas Karyawan adalah positif, jika Motivasi mengalami perubahan satu kali, maka akan menaikkan Produktivitas sebesar 0,912.
\end{abstract}

Kata Kunci : Motivasi, produktivitas

\section{PENDAHULUAN}

Sumber daya manusia merupakan faktor yang sangat sentral dalam organisasi, apapun bentuk dan tujuannya, organisasi dibuat berdasarkan berbagai visi dan misi untuk kepentingan manusia. Pentingnya sumber daya manusia dalam suatu organisasi, menuntut setiap organisasi mendapatkan pegawai yang berkualitas dan produktif untuk menjalankan organisasi. Untuk mencapai hal tersebut, maka perusahaan harus mampu menciptakan kondisi yang dapat mendorong karyawan untuk mengembangkan dan meningkatkan kemampuan serta keterampilan yang dimiliki karyawan. Salah satu upaya yang dapat ditempuh oleh perusahaan yaitu dengan memberikan motivasi dan kompensasi yang memuaskan sesuai dengan kinerja karyawan. Namun lebih dari itu motivasi merupakan hal terpenting untuk memberikan semangat karyawan agar membuat produktivitas yang tinggi guna mendapatkan keuntungan yang sebesar-besarnya.

Dengan memberikan motivasi perusahaan dapat meningkatkan produktivitas karyawan dan memberikan semangat kepada karyawan agar lebih giat bekerja demi mencapai tujuan yang telah ditetapkan perusahaan. 
Produktivitas

karyawan

merupakan kemampuan karyawan dalam berproduksi dibandingkan dengan input yang digunakan, seorang karyawan dapat dikatakan produktif apabila mampu menghasilkan barang atau jasa sesuai dengan diharapkan dalam waktu yang singkat atau tepat. Produktivitas karyawan juga dapat digambarkan sebagai tingkat keberhasilan dalam mencapai tujuan organisasi sehingga Produktivitas karyawan pada Instansi Balai Besar Cisadane sangat dibutuhkan. Instansi tersebut merupakan salah satu instansi yang berada dibawah Direktorat Jenderal Sumber Daya Air Kementerian Pekerjaan Umum dan Perumahan Rakyat yang mengatasi masalah banjir. Dalam Balai Besar Sungai Cisadane, Pegawai Negeri Sipil (PNS) merupakan perangkat kerja yang sangat menentukan keberhasilannya dalam mencapai tugas pokok dan fungsi (tupoksi), yang sering kali berhubungan dengan pelayanan kepada masyarakat baik manusia sebagai individu maupun manusia sebagai kelompok. Pegawai Negeri Sipil (PNS) adalah setiap warga Negara Republik Indonesia yang telah memenuhi syarat yang ditentukan, diangkat oleh pejabat yang berwenang dan diserahi tugas dalam suatu jabatan negeri, atau diserahi tugas negara lainnya, dan digaji berdasarkan peraturan yang berlaku dan ditingkatkan secara berkesinambungan.

Berdasarkan observasi pada Balai Besar Cisadane, peneliti mendapatkan fakta yang terjadi pada instansi tersebut bahwa produktivitas karyawan yang bekerja disana masih belum maksimal dan para pegawai hanya melakukan pekerjaan sesuai jobdesk yang sudah ada. Selain itu hal yang selalu dinanti-nanti pegawai adalah hari-hari mendekati gajian ataupun hari dimana bonus dari atasan turun. Hal tersebut membuktikan bahwa pegawai hanya produktif jika mendekati hari gajian, selain ituhal lain yang ditemukan dalam penelitian ini yaitu beberapa karyawan mengatakan bahwa apabila pekerjaan numpuk dan belum selesai itu bawaannya malas, ditambah lagi sudah ditagih untuk membuat laporan tambah semakin malas dan jadinya kurang produktif dan ditambah lagi kurangnya perhatian dari atasan.

Hal tersebut menunjukkan bahwa untuk menjadi produktif maka pegawai 
harus memiliki motivasi dalam hal ini berupa komisi atau bonus. Seperti yang diungkapkan oleh Handoko (2000:213) bahwa salah satu faktor yang mempengaruhi produktivitas karyawan adalah motivasi. Motivasi juga merupakan hal yang perlu diperhatikan oleh perusahaan atau instansi, karena jika ditinjau lebih lanjut terdapat kecenderungan bahwa karyawan yang mempunyai motivasi tinggi mampu mencapai prestasi kerja yang tinggi dan sebaliknya mereka yang mempunyai motivasi rendah kurang mampu dalam memenuhi target yang diterapkan oleh perusahaan atau instansi. Kinerja seorang karyawan akan baik apabila kebutuhannya untuk berprestasi (achievement), untuk mendapatkan kekuasaan (power), dan untuk afiliasi (affiliation) terpenuhi. Apabila kebutuhan-kebutuhan tersebut telah terpenuhi dalam diri seorang karyawan, maka karyawan akan menjadi termotivasi bekerja dan bersedia melaksanakan kegiatan kerja dengan kinerja yang baik. Seseorang yang sangat termotivasi yaitu orang yang melaksanakan upaya optimal untuk mencapai kinerjanya, sedangkan yang tidak termotivasi hanya memberikan upaya minimum dalam hal bekerja. Bila sekelompok pegawai dan atasannya mempunyai kinerja yang baik, maka akan berdampak pada kinerja organisasi yang baik pula (Robbins, 2006:117).

Adapun kompensasi berkaitan erat dengan kewajiban perusahaan atau instansi pada karyawan sebagaimana diatur oleh ketentuan internal instansi dan ketentuan lainnya. Dengan demikian analisis produktivitas karyawan dalam hal ini pegawai negeri sipil Balai Besar Cisadane didukung oleh motivasi Hal ini diharapkan dapat membentuk suatu hubungan baik antara karyawan dan perusahaan. Dimana para karyawan akan berfikir bahwa perusahaan tempat mereka bekerja bisa memahami dan memenuhi kebutuhan hidup yang menjadi alasan mereka bekerja, sehingga dapat dikatakan bahwa motivasi memiliki pengaruh terhadap produktivitas karyawan. Hal ini didukung oleh penelitian dari Agung (2012) yang mengungkapkan bahwa motivasi memiliki hubungan yang positif terhadap produktivitas karyawan di PDAM Tirta Moedal Semarang. Penelitian lainnya 
dilakukan oleh Lia Fauziah (2013) yang mengungkapkan bahwa terdapat hubungan yang positif dan signifikan atas pemberian pelatihan, motivasi, dan kepada karyawan dengan peningkatan kinerja karyawan.

Dari kedua penelitian diatas dapat dilihat bahwa motivasi memiliki hubungan yang positif dengan produktivitas karyawan. Akan tetapi kedua penelitian diatas dilakukan pada karyawan dari perusahaan swasta, dan ini berbeda dengan penelitian yang akan peneliti lakukan yaitu di lingkungan pegawai negeri sipil (PNS). Karena lingkungan kerja pada karyawan swasta dan pegawai negeri sipil jelaslah berbeda dan tuntutannya juga berbeda, sehingga inilah yang menjadi dasar penelitian yang akan dikembangkan oleh penulis, untuk melihat bagaimana motivasi berpengaruh terhadap peningkatan produktivitas karyawan..

\section{TINJAUAN PUSTAKA}

\section{MOTIVASI KERJA}

Istilah motivasi berasal dari kata Latin "movere" yang berarti dorongan atau menggerakkan.

Motivasi mempersoalkan bagaimana cara mengarahkan daya dan potensi agar bekerja mencapai tujuan yang ditentukan (Hasibuan, 2006: 141). Pada dasarnya seorang bekerja karena keinginan memenuhi kebutuhan hidupnya. Dorongan keinginan pada diri seseorang dengan orang yang lain berbeda sehingga perilaku manusia cenderung beragam di dalam bekerja.

Secara sistematis manajemen sumber daya manusia mempunyai fungsi yang sangat penting dalam sebuah perusahaan. Dari uraian tentang pengertian manajemen sumber daya manusia ini, akan dijalankan dua kategori fungsi yang meliputi fungsifungsi manajemen dan fungsi-fungsi operasional.

Fungsi - fungsi manajemen terdiri dari :Perencanaan berarti menentukan terlebih dahulu program ketenagakerjaan yang akan membantu pencapaian tujuan perusahaan yang telah ditetapkan. Penetapan tujuan tersebut tentu memerlukan partisipasi aktif dari semua manajer, sesuai dengan pengetahuan serta bidang tugasnya masing-masing. Dalam hal ini perlu dirancang susunan dari berbagai hubungan antara jabatan, personalia dan faktor fisik. Pengarahan adalah 
menggerakan orang-orang untuk penyimpangan yang tidak dapat diubah. bersedia bekerja secara efektif melaksanakan rencana yang telah ditetapkan.

\section{PRODUKTIVITAS}

Produktivitas merupakan salah satu aspek penting dalam meningkatkan kemampuan serta pemanfaatan sumber - sumber daya yang relative terbatas dengan mempergunakan seefisien mungkin. Berikut beberapa menurut para ahli mengenai produktivitas karyawan :

\section{Hasibuan}

(2006:41)

mengemukakan bahwa "Produktivitas merupakan perbandingan antara hasil (output) dengan masukan (input). Pengertian ini menjelaskan bahwa produktivitas merupakan suatu hal yang sangat penting bagi perusahaan bahkan menjadi prioritas organisasi”. Pengarahan dapat berupa pemberian motivasi serta pengendalian. Pengendalian yaitu pengamatan atas tindakan dan perbandingan dengan rencana dan perbaikan atas penyimpangan yang mungkin terjadi atau pada saat-saat tertentu, penyusunan kembali rencana-rencana dan penyesuaiannya terhadap
Fungsi manajemen ini berhubungan dengan pengaturan kegiatan agar sesuai dengan rencana yang telah dirumuskan berdasarkan analisis terhadap tujuan perusahaan.

\section{HIPOTESIS PENELITIAN}

$\mathrm{Ha}$ : Diduga Motivasi berpengaruh terhadap Produktivitas karyawan
Ho : Diduga Motivasi tidak berpengaruh terhadap
Produktivitas karyawan

\section{KERANGKA BERPIKIR \\ Gambar}

Kerangka Berpikir

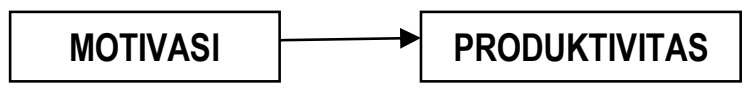

\section{ANALISA DATA DAN PEMBAHASAN}

Analisis hasil penelitian yang telah dilakukan, yaitu tentang Pengaruh Motivasi Karyawan terhadap Produktivitas Karyawan. Adapun data yang terkumpul dilakukan dengan cara menyebarkan angket kepada responden, yaitu para karyawan pada Balai Besar Cisadane.

\section{PENYAJIAN DATA}

Data yang peneliti diperoleh dari data primer dan sekunder penelitian. Data 
primer ini adalah hasil kuesioner yang disebarkan kepada 112 karyawan sebagai responden. Data tersebut merupakan data utama dimana hasilnya ditunjang oleh data-data sekunder yang analisisnya didapat dari hasil survey di lapangan dan beberapa sumber pustaka untuk memperkuat dan memperdalam hasil analisis. Data yang diperoleh dari hasil kuesioner terdiri dari dua macam, yaitu data responden dan data penelitian.

\section{DATA RESPONDEN}

Seluruh identitas responden yang relevan dengan permasalahan yang sedang diidentifikasi merupakan data responden. Data kuesioner akan diidentifikasi berdasarkan jenis kelamin, usia, dan pendidikan. Hal tersebut akam memberikan gambaran singkat tentang karakteristik

Tabel

Karakterisitk Berdasarkan Jenis Kelamin

\begin{tabular}{|c|c|c|}
\hline $\begin{array}{c}\text { Jenis } \\
\text { Kelamin }\end{array}$ & $\begin{array}{c}\text { Jumlah } \\
\text { Responden }\end{array}$ & $\begin{array}{c}\text { Presentase } \\
(\%)\end{array}$ \\
\hline Laki-laki & 60 & $53.57 \%$ \\
\hline Perempuan & 52 & $46.43 \%$ \\
\hline Jumlah & 112 & $100 \%$ \\
\hline
\end{tabular}

Sumber : Data penelitian

Penelitian yang ada dapat dilihat bahwa dari 112 responden, sebanyak 60 orang atau $53.57 \%$ merupakan laki-laki dan
52 orang atau $46.43 \%$ perempuan. Sehingga dapat disimpulkan bahwa sebagian besar responden pada Balai Besar Cisadane berjenis kelamin lakilaki.

Tabel

Karakteristik Berdasarkan Usia

\begin{tabular}{|c|c|c|}
\hline Usia & $\begin{array}{c}\text { Jumlah } \\
\text { Responden }\end{array}$ & Presentase(\%) \\
\hline $20-25$ & 12 & $11 \%$ \\
\hline $26-30$ & 35 & $31 \%$ \\
\hline $31-40$ & 41 & $37 \%$ \\
\hline $41-45$ & 11 & $9 \%$ \\
\hline$>46$ & 13 & $12 \%$ \\
\hline & 112 & $100 \%$ \\
\hline
\end{tabular}

Sumber : Data penelitian

Berdasarkan tabel diatas menunjukan umur responden 20-25 tahun sebanyak 12 orang atau $11 \%$., umur 26-30 tahun sebanyak 35 orang atau $31 \%$., umur 31-40 tahun sebanyak 41 orang atau $37 \%$, umur 41-45 tahun sebanyak 11 orang, atau $9 \%$., dan umur paling tua yaitu lebih dari 46 tahun sebanyak 13 orang atau $12 \%$. Sehingga dapat disimpulkan bahwa pegawai di Balai Besar Cisadane sebagian besar berusia 31-40 tahun.

Tabel

Karakteristik Berdasarkan Pendidikan

\begin{tabular}{|c|c|c|}
\hline Pendidikan & $\begin{array}{c}\text { Jumlah } \\
\text { Responden }\end{array}$ & $\begin{array}{c}\text { Presentase } \\
(\%)\end{array}$ \\
\hline SMA & 5 & $5 \%$ \\
\hline DIPLOMA & 10 & $9 \%$ \\
\hline S1 & 81 & $72 \%$ \\
\hline S2 & 16 & $14 \%$ \\
\hline Jumlah & 112 & $100 \%$ \\
\hline
\end{tabular}


Berdasarkan tabel di atas kemudian juga dapat dilihat bahwa sebagian besar PNS pada Balai Besar Cisadane adalah lulusan S1 sebanyak 81 orang atau $72 \%$ sisanya sebanyak 16 orang atau $14 \%$ lulusan S2, 10 orang atau 9\% lulusan Diploma dan sebanyak 5 orang atau 5\% lulusan SMA.

\section{ANALISIS DATA DAN}

\section{PEMBAHASAN UJI VALIDITAS}

Uji Validitas digunakan untuk mengukur derajat ketepatan dalam setiap item pertanyaan suatu kuesioner, pertanyaan-pertanyaan dalam kuesioner dapat dikatakan valid apabila pertanyaan tersebut mampu mengungkapkan sesuatu yang akan diukur oleh kuesioner tersebut. Teknik yang digunakan untuk uji validitas ini adalah "korelasi product moment" dari Pearson dengan tingkat kepercayaan 95\% $(\alpha=0,05)$ dilakukan dengan cara mengkorelasikan skor masing-masing item dengan $\mathrm{r}$ hitung $>\mathrm{r}$ tabel dan $\mathrm{n}=$ 112, sehingga item pertanyaan tersebut dapat dikatakan valid. Setelah dilakukan pengolahan data dengan menggunakan bantuan aplikasi program SPSS uji validitas dapat disajikan dalam tabel berikut ini:
Tabel

Hasil Pengujian Validitas Motivasi

\begin{tabular}{|c|c|c|c|}
\hline No & $\begin{array}{c}\text { Koefisien } \\
\text { Korelasi (r) }\end{array}$ & $\begin{array}{c}\text { Nilai Kritis } \\
\text { (r-tabel) }\end{array}$ & Ket \\
\hline P1 & $\mathbf{0 , 9 7 3}$ & 0,361 & Valid \\
P2 & $\mathbf{0 , 9 5 4}$ & 0,361 & Valid \\
P3 & $\mathbf{0 , 9 7 3}$ & 0,361 & Valid \\
P4 & $\mathbf{0 , 8 7 9}$ & 0,361 & Valid \\
P5 & $\mathbf{0 , 9 6 1}$ & 0,361 & Valid \\
P6 & $\mathbf{0 , 3 7 2}$ & 0,361 & Valid \\
P7 & $\mathbf{0 , 6 0 6}$ & 0,361 & Valid \\
P8 & $\mathbf{0 , 9 7 3}$ & 0,361 & Valid \\
P9 & $\mathbf{0 , 9 7 3}$ & 0,361 & Valid \\
P10 & $\mathbf{0 , 5 4 8}$ & 0,361 & Valid \\
P11 & $\mathbf{0 , 6 6 9}$ & 0,361 & Valid \\
P12 & $\mathbf{0 , 8 1 2}$ & 0,361 & Valid \\
P13 & $\mathbf{0 , 5 7 8}$ & 0,361 & Valid \\
P14 & $\mathbf{0 , 5 9 4}$ & 0,361 & Valid \\
& & & \\
\hline
\end{tabular}

Pada tabel di atas dapat dilihat nilai $r$ hitungnya, dimana setiap butir pernyataan yang dilakukan untuk mengukur variabel motivasi, nilai $\mathrm{r}$ hitung keseluruhannya diatas 0,361 yang berarti bahwa setiap butir pernyataan dari variabel motivasi adalah valid.

Tabel

Hasil Pengujian Validitas Produktivitas

\begin{tabular}{|c|c|c|c|}
\hline No & $\begin{array}{c}\text { Koefisien } \\
\text { Korflasi (r) }\end{array}$ & $\begin{array}{c}\text { Nilai Kritix } \\
\text { (r-takel) }\end{array}$ & Ket. \\
\hline $\mathrm{P1}$ & 0,665 & 0,361 & Vald \\
\hline P2 & 0,813 & 0,361 & Vafid \\
\hline P3 & 0,676 & 0,361 & Vafid \\
\hline P4 & 0,443 & 0,361 & Vafid \\
\hline P5 & 0,814 & 0,361 & Vafid \\
\hline P6 & 0,790 & 0,361 & Vafid \\
\hline P7 & 0,792 & 0,361 & Vafid \\
\hline$P 3$ & 0,451 & 0,361 & Vafid \\
\hline Pg & 0,517 & 0,361 & Vafid \\
\hline P10 & 0,681 & 0,361 & Vafid \\
\hline P11 & 0,555 & 0,361 & Vafid \\
\hline P12 & 0,799 & 0,361 & Vafid \\
\hline P13 & 0,669 & 0,361 & Vafid \\
\hline P14 & 0,800 & 0,361 & Valid \\
\hline P15 & 0,723 & 0,361 & Vafid \\
\hline P16 & 0,590 & 0,361 & Vald \\
\hline P17 & 0,596 & 0,361 & Valid \\
\hline $\mathrm{P} 13$ & 0,665 & 0,361 & Vafd \\
\hline
\end{tabular}

7 Fakultas Ekonomi - Universitas Dirgantara Marsekal Suryadarma 
Pada tabel diatas dapat dilihat nilai $\mathrm{r}$ hitungnya, dimana setiap butir pernyataan yang dilakukan untuk mengukur variabel produktivitas kerja, nilai $r$ hitung keseluruhannya diatas 0,361 yang berarti bahwa setiap butir pernyataan dari variabel produktivitas karyawan adalah valid.

\section{UJI REALIBILITAS}

Reliabilitas adalah suatu indeks yang menunjukkan sejauh mana hasil suatu pengukuran dapat dipercaya. Hasil pengukuran dapat dipercaya atau reliabel hanya apabila dalam beberapa kali pelaksanaan pengukuran terhadap kelompok subjek yang sama diperoleh hasil yang relatif sama, selama aspek yang diukur dalam diri subjek memang belum berubah. Cara yang digunakan untuk menguji reliabilitas kuesioner adalah dengan menggunakan Rumus Koefisien Cronbach Alpha.

Pengujian reliabilitas terhadap seluruh item atau pertanyaan pada penelitian ini akan menggunakan rumus koefisien Cronbach Alpha. Nilai Cronbach Alpha pada penelitian ini akan digunakan nilai 0,6 dengan asumsi bahwa daftar pertanyaan yang diuji akan dikatakan reliabel bila nilai
Cronbach Alpha $\geq 0.6$ (Ghozali, 2011:48). Hasil uji reliabilitas terhadap variable penelitian dapat dilihat dari tabel dibawah ini.

\begin{tabular}{|c|c|c|}
\hline \multicolumn{3}{|c|}{$\begin{array}{c}\text { Tabel } \\
\text { Uji Reliability }\end{array}$} \\
\hline Cronbach's Alpha & $\begin{array}{c}\text { Cronbach's Alphs } \\
\text { Based on Standardized } \\
\text { Items }\end{array}$ & N of Items \\
\hline 947 &, 60 & 14 \\
\hline 927 & 60 & 18 \\
\hline
\end{tabular}

Dari tabel diatas dapat dilihat bahwa nilai reliabilitas dari hasil pengujian adalah sebesar 0,947 untuk motivasi dan 0,927 untuk produktivitas sehingga dapat dikatakan bahwa 2 (dua) data penelitian reliabel karena memiliki nilai Cronbach's Alpha lebih besar dari 0,60 .

\section{UJI NORMALITAS}

Uji normalitas bertujuan untuk membuktikan bahwa variabel bebas dan terikat mempunyai distribusi normal.

Tabel

Uji Normalitas

One-Sample Kolmogorov-Smirnov Test

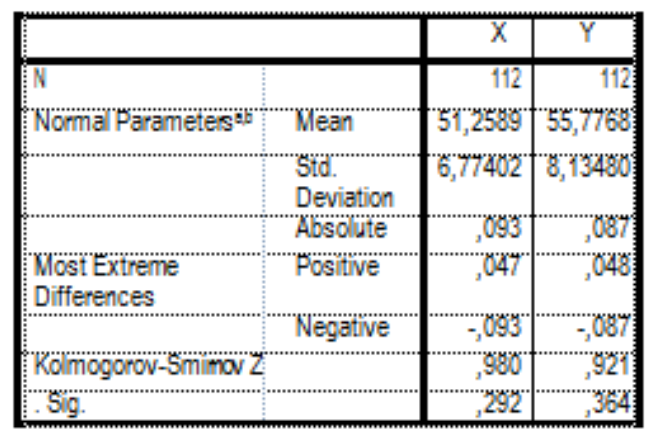


a. Test distribution is Normal.

b. Calculated from data.

Berdasarkan tabel di atas dapat diketahui bahwa nilai signifikansi untuk variabel motivasi (X) adalah sebesar 0,292 dan nilai signifikansi untuk variabel produktivitas karyawan (Y) adalah sebesar 0,364. Nilai signifikansi untuk semua variabel adalah lebih besar dari 0,05 maka dapat disimpulkan bahwa Ha diterima dan Ho ditolak atau dengan kata lain data pada variabel motivasi dan produktivitas karyawan berdistribusi normal.

\section{UJI LINEARITAS}

Uji linearitas disini digunakan untuk melihat apakah terjadi hubungan yang linier antara variabel bebas dengan variable terikat. Berikut merupakan penjelasan tentang uji linieritas yang terjadi antar variabel bebas Motivasi dan Variabel terikat Produktivitas.

Tabel

Uji Linearitas

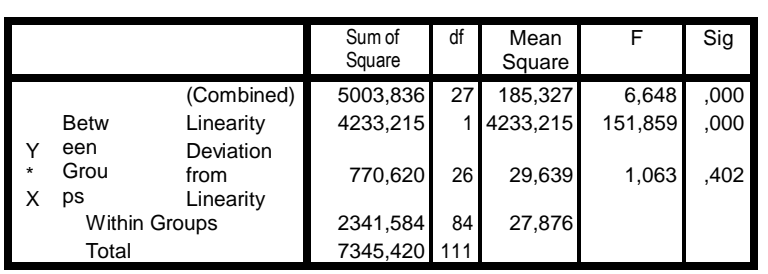

Berdasarkan tabel di atas dapat diketahui bahwa nilai signifikansi pada linearity sebesar 0,000 Nilai signifikansi adalah lebih kecil dari 0,05 maka dapat disimpulkan bahwa variabel motivasi (X) memiliki pengaruh yang linier secara signifikan terhadap variabel produktivitas (Y).

\section{UJI KORELASI}

Uji kolerasi digunakan untuk mengetahui atau mengukur keeratan/kekuatan dan arah pengaruh antara dua variabel. Di bawah ini adalah hasil perhitungan uji korelasi antara variabel motivasi terhadap produktivitas karyawan terhadap produktivitas karyawan menggunakan software SPSS:

Tabel

Uji Korelasi

Motivasi dan Produktivitas

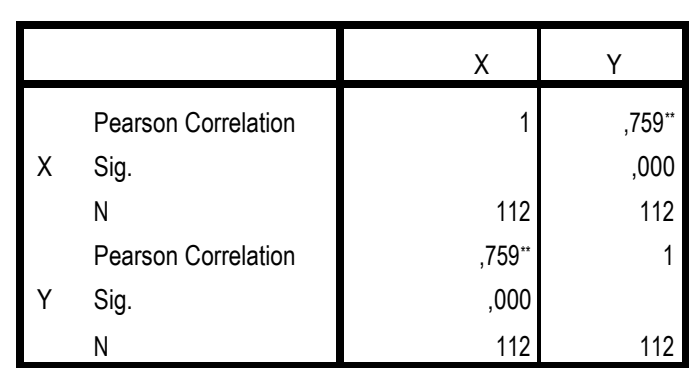

$\stackrel{* \star \text { Correlation is significant at the } 0.01 \text { level }}{ }$

Berdasarkan hasil analisis korelasi product moment pearson pada tabel di atas untuk variabel $\mathrm{X}$ dengan $\mathrm{Y}$ memiliki hubungan positif dengan tingkat sedang yang ditunjukan oleh 
nilai $r$ Pearson Correlation sebesar 0,759. Signifikansi koefisien korelasi ditunjukkan dengan probabilitas signifikansi sebesar $0,000<0,05$ maka signifikan. Hal ini menunjukkan pengaruh yang positif antara motivasi (X) dengan produktivitas karyawan (Y) tersebut signifikan atau nyata dalam statistik.

\section{UJI REGRESI LINIER}

\section{SEDERHANA}

Untuk mengetahui seberapa besar pengaruh variabel motivasi terhadap produktivitas karyawan Balai Besar Cisadane, maka dilakukan perhitungan persamaan regresi sederhana. Hasil linier sederhana dapat dilihat dalam tabel berikut

Tabel

Uji Regresi Linear Sederhana

\begin{tabular}{|l|r|r|l|l|l|}
\hline Model & \multicolumn{2}{|l|}{$\begin{array}{l}\text { Unstandardized } \\
\text { Coefficients }\end{array}$} & $\begin{array}{l}\text { Standar } \\
\text { dized } \\
\text { Coeffici } \\
\text { ents }\end{array}$ & T & \multirow{2}{|l|}{} \\
\cline { 2 - 6 } & B & $\begin{array}{l}\text { Std. } \\
\text { Error }\end{array}$ & Beta & & \\
\hline (Constant) & 9,047 & 3,853 & & 2,348 &, 021 \\
1 &, 912 &, 075 &, 759 & 12,232 &, 000 \\
\hline
\end{tabular}

a. Dependent Variable: $Y$

Berdasarkan tabel di atas menunjukkan nilai konstanta sebesar 9,047 dan koefisien b (slope) Motivasi sebesar
0,912, dengan demikian diperoleh persamaan regresi linier sederhana untuk menyatakan pengaruh Motivasi terhadap Produktivitas (Y) yaitu:

$$
=9,047+0,912
$$

\section{UJI KOEFISIEN REGRESI SECARA PARSIAL (UJI T)}

Uji ini digunakan untuk mengetahui apakah dalam model regresi variabel independen secara parsial berpengaruh secara signifikan terhadap variabel dependen (Y).

t tabel dalam uji ini dapat dilihat dalam lampiran titik persentase distribusi $\mathrm{t}$ yang ditentukan melalui signifikansi $\alpha=0,05: 2=0,025$ dengan derajat kebebasan (jumlah sampeljumlah variabel independen-1) $=(112-$ $1-1)=110$, yaitu sebesar 1,982 .

Tabel Hasil Uji t

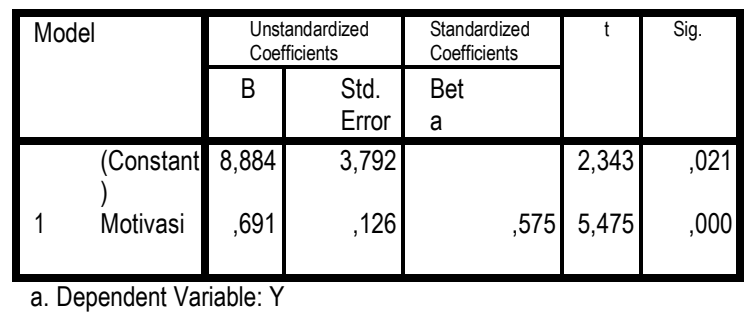

Berdasarkan tabel di atas dapat dilihat bahwa Nilai > $(5,475>1,982)$, maka variabel motivasi berpengaruh 
signifikan terhadap produktivitas karyawan.

\section{KESIMPULAN DAN SARAN}

\section{KESIMPULAN}

Berdasarkan pada analisa data dan pembahasan pada bab sebelumnya, maka pada penelitian ini dapat diambil kesimpulan bahwa nilai konstanta sebesar 9,047 menunjukkan jika Motivasi nilainya adalah 0 , maka Produktivitas karyawan nilainya positif yaitu sebesar 0,912, nilai koefisien regresi (slope) sebesar 0,912 menunjukkan besarnya pengaruh Motivasi terhadap Produktivitas karyawan adalah positif, jika Motivasi mengalami perubahan satu kali, maka akan menaikkan Produktivitas karyawan sebesar 0,912 .

\section{SARAN}

Berdasarkan pada kesimpulan yang diperoleh dalam penelitian ini, maka saran yaitu dalam upaya meningkatkan produktivitas karyawan Balai Besar Cisadane, adalah berdasarkan hasil analisis tanggapan responden motivasi sangatlah berpengaruh terhadap produktivitas karyawan Balai Besar Cisadane, maka selanjutnya agar tetap mempertahankan motivasi yang baik yang pada akhirnya akan meningkatkan produktivitas karyawan lebih baik lagi.

\section{DAFTAR PUSTAKA}

Agung.2012. Pengaruh Motivasi Dan Kompensasi Terhadap Produktivitas Karyawan di PDAM Tirta Moedal Semarang.Skripsi. Semarang: Undip

Dessler, G, 1998. Manajemen Sumber Daya Manusia, Jakarta: Prenhallind-o Fauziah, Lia. 2013. Pengaruh Motivasi, Pelatihan Dan Kompensasi Terhadap Produktivitas Kerja

Kinerja Karyawan PT. Nadira Prima Semarang.Skripsi. Semarang: Udinus

Ghozali, Imam. 2011. Aplikasi Analisis Multivariate Dengan Program IBM. SPSS 19 (edisi kelima.) Semarang: Universitas Diponegoro

Hani Handoko, T.2000.Manajemen Produksi dan Operasi. Yogyakarta: BPFE. Hasibuan, Malayu SP, 2006. Manajemen Sumber Daya Manusia, Jakarta: Bumi Aksara

Heidjrachman Ranupandojo dan Suad Husnan. 2002. Manajemen Personalia.

Yogyakarta: BPFE

J. Supranto, 2001. Statistik Teori dan Aplikasi, Cetakan Kedua, Jakarta: Penerbit Erlangga.

Mangkunegara, Anwar Prabu . 2005. Sumber Daya Manusia perusahaan. Bandung : Remaja. Rosdakarya 
Mangkuprawira, 2002, Manajemen Sumber Daya Manusia Strategik, Jakarta: Penerbit Ghalia. Indonesia

Martoyo, S. 2000, Manajemen Sumber Daya Manusia, Yogyakarta: BPFE Muslimah.2014. Pengaruh Kompensasi Terhadap Produktivitas Kerja Pada

Karyawan Tetap Dan Karyawan Kontrak PT. Dan Liris Indonesia.Skripsi. Yogyakarta: UNY

Purwanto, Ngalim, 2006. Psikologi Pendidikan. Bandung: Remaja Rosdakarya. Robbinss Stephen P., 2006. Organizational Behavior (Terjemahan) Jilid 1, Edisi

Kedelapan, PT. Bhuana Ilmu Populer, Jakarta

Ruky, Achmad. 2001. Sistem Manajemen Kinerja. Jakarta: PT. Gramedia Pustaka.

Utama

Sedarmayanti. 2001. Sumber Daya Manusia dan Produktivitas Kerja. Bandung: Mandar Maju.

Simamora, Henry, 2004. Manajemen Sumber Daya Manusia, Yogyakarta: STIE- YKPN

Sinungan, Muchdarsyah. 2003. Produktivitas apa dan Bagaimana. Jakarta: Bumi Aksara

Sugiyono. 2004. Metode Penelitian Bisnis: Penerbit CV. Alfabeta: Bandung 2008.Metodologi Penelitian Bisnis. Alfabeta. Bandung (2010), Metode Penelitian Kuantitatif Kualitatif dan R\&D, Alfabeta, Bandung.

Tampi, G.S, 2013.Kepemimpinan dan Kompensasi Pengaruhnya terhadap Kinerja Karyawan dan Dampaknya terhadap Organization Citizenship
Behavior.Jurnal EMBA, Vol 1 No.3: 921-929

http://bbwsciliwungcisadane.com/profil/org anisasi 